\title{
Morphometric parameters and level of Salmonella and Escherichia coli contamination of Tilapia guineensis and Sarotherodon melanotheron in the waterway of Southern Benin
}

\author{
Tossou Jacques Dougnon ${ }^{1}$ and Antoine Chikou ${ }^{2}$
}

1. Laboratory of Research in Applied Biology, Polytechnic School of Abomey-Calavi, University of Abomey-Calavi, 01 BP 2009 Abomey-Calavi, Benin; 2. Laboratory of Hydrobiology and Aquaculture, Faculty of Agronomic Sciences, University of Abomey-Calavi, 01 BP 526, Cotonou, Benin.

Corresponding author: Tossou Jacques Dougnon, e-mail: dougnonj@yahoo.fr, AC: chikoua@yahoo.fr

Received : 24-11-2015, Revised: 13-01-2016, Accepted: 27-01-2016, Published online: 12-02-2016

How to cite this article: Dougnon TJ, Chikou A. Morphometric parameters and level of Salmonella and Escherichia coli contamination of Tilapia guineensis and Sarotherodon melanotheron in the waterway of Southern Benin, Int J One Health 2016;2: 1-6.

\begin{abstract}
Aim: The present study aims to evaluate the morphometric parameters and level of Salmonella and Escherichia coli contamination of Tilapia guineensis and Sarotherodon melanotheron in the waterway of Southern Benin.

Materials and Methods: 183 T. guineensis and 195 S. melanotheron were collected from June to July 2014 in four waterways: Lake Ahémé, Nokoué Lake, coastal lagoon, and lagoon of Porto-Novo. Weight, total length, and standard length of these fish were evaluated. E. coli and Salmonella sp. were sought in fresh fish.

Results: The results obtained in this study indicate that $S$. melanotheron presented high-performance of length and weight more than $T$. guineensis in Ahémé Lake and lagoon of Porto-Novo. However, in Nokoué Lake and coastal lagoon, no difference was observed between the two species of fish. As for bacteriological analysis, the population of T. guineensis was more contaminated with $E$. coli with respective values of $60 \%$ and $59.52 \%$ in the Nokoué Lake and coastal lagoon than in the two other streams. Regarding the population of $S$. melanotheron, she was most contaminated in the coastal lagoon with a percentage of $66.66 \%$ in Ahémé Lake, Nokoué Lake, and the lagoon of Porto-Novo. However, no Salmonella germ was detected in fish analyzed in this study.
\end{abstract}

Conclusion: It appears that the morphometric parameters and weight of T. guineensis are lower than those of S. melanotheron. The evaluation of the microbiological quality revealed that $T$. guineensis is more contaminated with E. coli that S. melanotheron.

Keywords: benin, Escherichia coli, morphometric parameters, Salmonella sp., Sarotherodon melanotheron, Tilapia guineensis.

\section{Introduction}

Food security is today a challenge for the authorities. People are facing an animal protein deficit. Fishing is one of the very important activities to overcome this problem. Furthermore, fishing is a veritable source of animal protein for the majority of the world population.

In Benin, the national fish production is estimated at 40,363.63 tons in 2012 [1]. Despite this contribution, the supply of fish products is below market needs that are around $8,657,033$ tons [1]. In view of the gap between supply and demand plus the decline in fisheries production [2], Benin is dependent on foreign countries for fishery products. This situation resulted in massive imports of frozen fish from neighboring countries and Europe. Fish products are preferred food because they are inexpensive, acceptable, and accessible to the consumers. However, the skin, shell, mucus, gills and gastrointestinal tract of these animals contain a significant

Copyright: The authors. This article is an open access article licensed under the terms of the Creative Commons Attributin License (http:// creative commons.org/licenses/by/2.0) which permits unrestricted use, distribution and reproduction in any medium, provided the work is properly cited. number of microbial floras [3]. In the United States, Olsen et al. [4] reported that fish was an accessory to $25 \%$ of the recorded food poisoning.

The sanitary degradation of the aquatic environment due to the increase in the lacustrine population of Benin affects the aquatic fauna of the Lake [5]. Therefore, it is important to evaluate the morphometric parameters of fish species in some waterways in South Benin. It should also be taken into account the presence of zoonotic gastrointestinal bacteria such as Salmonella spp. and Escherichia coli in their bodies. Tilapia guineensis and S. melanotheron are two Indigenous species of cichlid of the Benin water which are strongly consumed. The present study evaluates the morphometric parameters and the presence of Salmonella and E. coli in two species of cichlid in some streams in Southern Benin.

\section{Materials and Methods}

\section{Ethical approval}

This study has been approved by the University of Abomey-Calavi Research Ethics Committee. We note that all animals used for this research is with permission of Animal Ethics Committee of University of Abomey-Calavi. 


\section{Collection of fish}

T. guineensis and S. melanotheron were collected in four wild waterways in southern Benin: Ahémé Lake, Nokoué Lake, coastal lagoon, and the lagoon of PortoNovo. The age of the fish was not established. Collected fish were transported in 1 or $2 \mathrm{~h}$ maximum from the site to the Veterinary Clinical Laboratory and Pharmacy Complex of Animal Health Production of the University of Abomey-Calavi for morphometrical and microbiological analyzes. A temperature of $4^{\circ} \mathrm{C}$ was maintained during transport to avoid deterioration of the specimen.

\section{Morphometrical analyzes}

Total length, standard length, and weight measurements

Once at the laboratory, fishes were immediately weighed with a digital scale $\left(\mathrm{KERN}^{\circledR}\right.$ : $\max 220 \mathrm{~g}, \mathrm{~d}=0.1 \mathrm{mg}$ ). Figure-1 shows the total length and the standard length of collected fish were taken with an ichtyometer.

\section{Evaluation of the relationship weight-lengt}

The type of growth presented by the fish was evaluated through the weight-length relationship. This exponential relationship between weight and length is computed based on Le Cren, (1951); the formula is as follows:

$\mathrm{W}=\mathrm{a} \mathrm{TL}^{\mathrm{b}}$

Where: $\mathrm{W}=$ Fish weight $(\mathrm{g})$;

$\mathrm{TL}=$ Total length of the fish $(\mathrm{cm})$;

$\mathrm{a}=$ Coefficient related to the environment of fish (y-intercept of the regression line);

$\mathrm{b}=$ The coefficient of relative growth and (b) as the relative growth rate of the mass (slope of the regression line).

The coefficient $b$ varies between 2 and 4 . It expresses the relative shape of the body of a fish. When it is equal to 3, fish growth is isometric; below 3, it's allometric, but when coefficient $b$, is above 3 , it indicates better growth in weight and length and viz. [6].

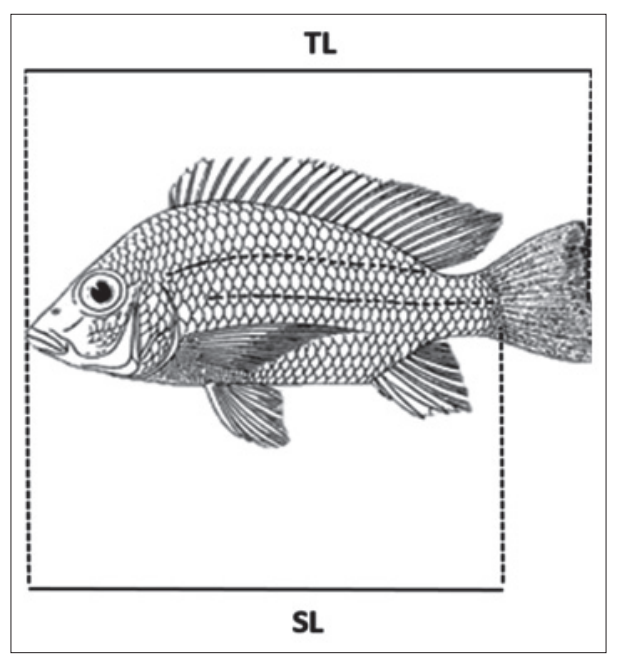

Figure-1: Body measurements taken on each fish (total length ( $T L)$, standard length (SL))

\section{Microbiological analyzes}

Detection of E. coli

After morphometric analyzes, each fish sample was aseptically dissected to expose the abdominal region. The intestine was removed and cut into small pieces.

A sample of $25 \mathrm{~g}$ of intestine was removed. To this sample, $225 \mathrm{ml}$ of buffered peptone water (Oxoid CM0509 lot 1390836, England) was added to obtain a stock solution. Successive dilutions were performed until $10^{-4}$ from the stock solution. $1 \mathrm{ml}$ of each dilution was inoculated by incorporating on the medium RAPID E. coli 2 . After incubation at $44^{\circ} \mathrm{C}$ for $24 \pm 2 \mathrm{~h}$, the reading was taken. The colonies of $E$. coli are purple, and those of thermotolerant coliforms are blue.

\section{Detection of Salmonella sp.}

For detection of Salmonella sp., $225 \mathrm{ml}$ of buffer peptone water (Oxoid CM0509 lot 1390836, England) was added to $25 \mathrm{~g}$ of sample intestine. After incubation at $37^{\circ} \mathrm{C}$ for $18 \mathrm{~h}, 0.1 \mathrm{ml}$ of this culture was inoculated in $10 \mathrm{ml}$ Rappaport-Vassiliadis broth (Bio-Rad lot 098282, France) and $2 \mathrm{ml}$ in $20 \mathrm{ml}$ of broth Mueller Kaufman. The incubation was performed at $37^{\circ} \mathrm{C}$ for $24 \pm 4$ h. The isolation of Salmonella was done by seeding xylose lysine decarboxylase media (Oxoid CM0469 lot 1399006, United Kingdom) and Hektoen (Oxoid CM0419 lot 1423494, England). Selecting Salmonella characteristic colonies were made after incubation at $37^{\circ} \mathrm{C}$ for $24 \pm 4 \mathrm{~h}$. The discrimination test was performed by inoculating the urea indole medium. Salmonella is devoid of urease [7]. The API $20 \mathrm{E}$ gallery was finally planted.

\section{Statistics analysis}

Morphometric parameters measured were encoded in Excel and statistically analyzed using SAS [8]. Proc GLM procedure was used for the analysis of variance. The F-test was used to determine the significance of the effect species. Means were compared pairwise by the Student's t-test. The Chi-square test was used to determine the significance of the frequencies of bacterial contamination levels by species and waterways. The test bilateral of $\mathrm{Z}$ was used to compare pairwise the frequency.

\section{Results}

\section{Morphometric analyzes}

Total length, standard length, and weight measurements

In Ahémé Lake, the average values of morphometric parameters were, respectively, $133.58 \pm 1.98$ and $102.56 \pm 1.53 \mathrm{~mm}$ for the average total length and the average standard length for $S$. melanotheron. On the other hand, in $T$. guineensis, the average total length was $116.22 \pm 2.19 \mathrm{~mm}$ with an average standard length of $88.24 \pm 1.70 \mathrm{~mm}$.

The average body weight was $48.1 \pm 1.62 \mathrm{~g}$ in $S$. melanotheron against $32.44 \pm 1.79 \mathrm{~g}$ in $T$. guineensis. 


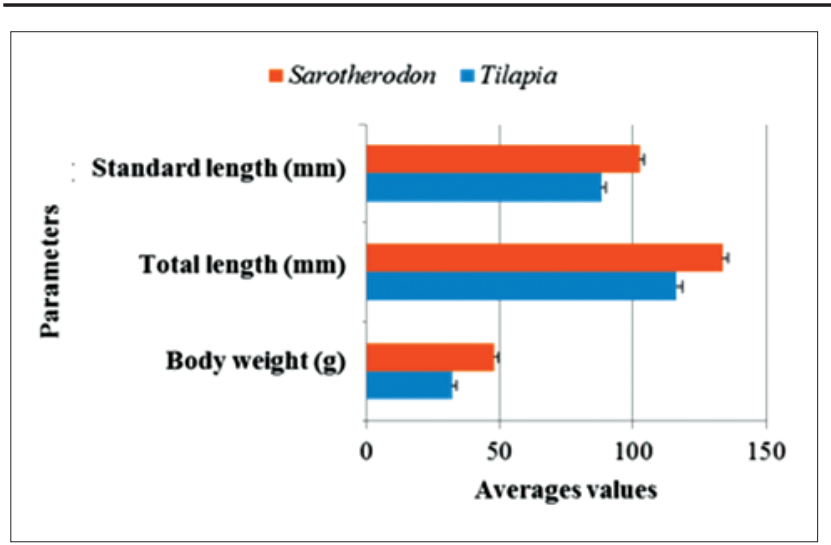

Figure-2: Morphometric parameters of Tilapia guineensis and Sarotherodon melanotheron in Ahémé Lake

These parameters varied significantly between the two species in the rivers $(\mathrm{p}<0.001)$ (Figure-2).

In Nokoué Lake, the average total length and average standard length were, respectively, $161.64 \pm 2.83,123.16 \pm 2.19 \mathrm{~mm}$ for $S$. melanotheron. These parameters were, respectively, $156.34 \pm 2.83$ and $119.42 \pm 2.19 \mathrm{~mm}$ in $T$. guineensis. The average body weight in $S$. melanotheron was $86 \pm 4.47$ and $80.60 \pm 4.47 \mathrm{~g}$ in $T$. guineensis (Figure-3). In this stream, both species showed no significant difference between their's morphometric parameters ( $p>0.05)$.

In the coastal lagoon, the average total length and average standard length for $S$. melanotheron were, respectively, $131.6 \pm 2.96$ and $98.87 \pm 2.29 \mathrm{~mm}$. In T. guineensis, the average total length was $128.31 \pm 3.06 \mathrm{~mm}$ and the average standard length was $96.64 \pm 2.37 \mathrm{~mm}$. As regards the body weight, $S$. melanotheron weighed $52.44 \pm 3.13$ against $44.93 \pm 3.24 \mathrm{~g}$ for $T$. guineensis (Figure-4). These parameters have not varied significantly between the two species in the lagoon ( $\mathrm{p}>0.05$ ).

However, in the lagoon of Porto-Novo, the total length of $S$. melanotheron and $T$. guineensis was, respectively, $176.28 \pm 3.73$ and $161.28 \pm 3.73 \mathrm{~mm}$, with respective average standard lengths of $135.54 \pm 2.91$ and $123.88 \pm 2.91 \mathrm{~mm}$. In this stream, the average body weight of $S$. melanotheron was $113 \pm 6.66$ against $89.70 \pm 6.66 \mathrm{~g}$ in $T$. guineensis. The statistical analysis showed that there is a significant difference between these parameters in these two species $(p<0.01)$ (Figure-5).

Figure-6 shows the morphometric parameters of $S$. melanotheron and T. guineensis. The total length and standard length of $S$. melanotheron were, respectively, $151.27 \pm 2.00$ and $115.45 \pm 1.57 \mathrm{~mm}$ against, respectively, $142.27 \pm 2.06$ and $108.43 \pm 1.62 \mathrm{~mm}$ in T. guineensis.

As regards the weight of $S$. melanotheron, it was $75.46 \pm 2.87$ against $64.11 \pm 2.96 \mathrm{~g}$ in $T$. guineensis. For these three parameters, the values were significantly different between the two species $(p<0.01)$.

Table-1 shows the morphometric parameters of T. guineensis in different streams. The body weight of T. guineensis in Nokoué Lake $(80.60 \pm 4.20 \mathrm{~g})$ and in

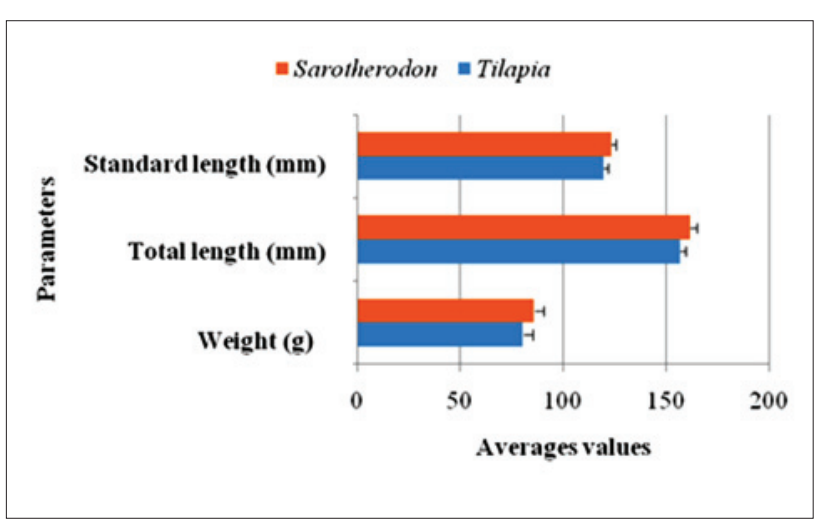

Figure-3: Morphometric parameters of Tilapia guineensis and Sarotherodon melanotheron in NokouéLake

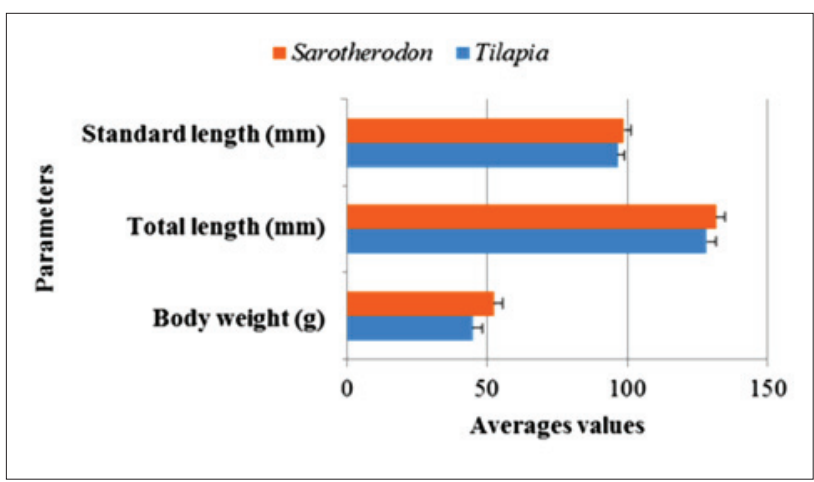

Figure-4: Morphometric parameters of Tilapia guineensis and Sarotherodon melanotheron in coastal lagoon

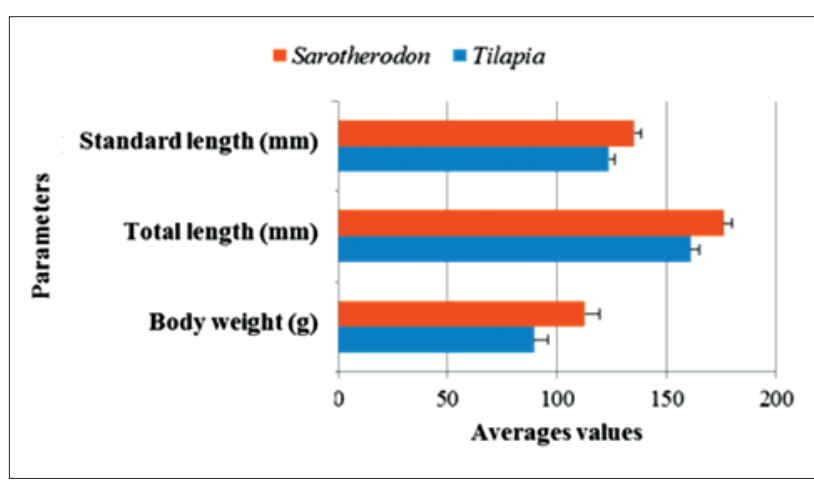

Figure-5: Morphometric parameters of Tilapia guineensis and Sarotherodon melanotheron in the lagoon of Porto-Novo

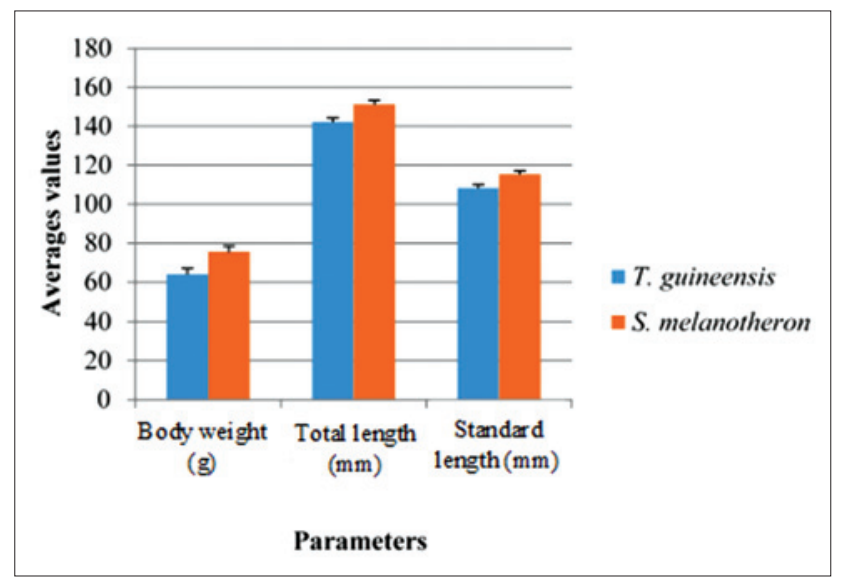

Figure-6: Morphometric parameters of Tilapia guineensis and Sarotherodon melanotheron compared in different streams 
Table-1: Morphometric parameters of Tilapia guineensis in different streams.

\begin{tabular}{|c|c|c|c|c|c|}
\hline Parameters & $\begin{array}{l}\text { Aheme Lake } \\
\quad(n=41)\end{array}$ & $\begin{array}{l}\text { Nokoue Lake } \\
\quad(n=50)\end{array}$ & $\begin{array}{c}\text { coastal lagoon } \\
(n=49)\end{array}$ & $\begin{array}{l}\text { Porto-Novo lagoon } \\
\quad(n=50)\end{array}$ & Significance \\
\hline & $116.22 \pm$ & 156.34 & $128.31 \pm 2.91^{\mathrm{b}}$ & $2.66^{a}$ & $* * *$ \\
\hline Standard length (mm) & $88.24 \pm 2.35^{c}$ & $119.42 \pm 2.13^{\mathrm{a}}$ & $96.64 \pm 2.33^{b}$ & $123.88 \pm 2.13^{\mathrm{a}}$ & $* * *$ \\
\hline Body weight (g) & $32.44 \pm 4.64^{b}$ & $80.60 \pm 4.20^{a}$ & $44.93 \pm 4.58^{b}$ & $89.70 \pm 4.20^{a}$ & $* * *$ \\
\hline
\end{tabular}

Averages in the same row followed by different letters are significantly different at the $5 \%$; ***p $<0,001$

the lagoon of Porto-Novo $(89.70 \pm 4.20 \mathrm{~g})$ did not differ significantly $(p>0.05)$. However, the body weight of this species in these two waterways is higher than the coastal lagoon and Ahémé Lake where the respective values of this parameter were $44.93 \pm 4.58$ and $32.44 \pm 4.64 \mathrm{~g}(\mathrm{p}<0.05)$. As for the average total length, T. guineensis from Nokoué Lake and PortoNovo lagoon showed the highest values $(156.34 \pm 2.66$ and $161.28 \pm 2.66 \mathrm{~mm}$, respectively) compared to those living in the Ahémé Lake and coastal lagoon. Furthermore, T. guineensis had a higher total length in the coastal lagoon than Lake Ahémé with respective values of $128.31 \pm 2.91$ and $116.22 \pm 2.94 \mathrm{~mm}$ $(\mathrm{p}<0.05)$. Regarding the standard length, it was higher in T. guineensis living in Nokoué Lake and PortoNovo lagoon than the ones living in the coastal lagoon $(\mathrm{p}<0.05)$.

In addition, $T$. guineensis of the coastal lagoon was longer than the ones of Ahémé Lake. In sum, T. guineensis of Nokoué Lake and Porto-Novo lagoon had the highest morphometric parameters $(\mathrm{p}<0.001)$.

\section{Morphometric parameters in S. melanotheron compared in different waterways}

In the lagoon of Porto-Novo, the body weight, the total length, and standard length were, respectively, $113.00 \pm 4.65 \mathrm{~g}, 176.28 \pm 3.15$, and $135.54 \pm 2.4 \mathrm{~mm}$ for $S$. melanotheron. The values of these parameters were lower for those living in the Nokoué Lake with respective values of $86 \pm 4.65 \mathrm{~g}, 161.64 \pm 3.15$, and $123.16 \pm 2.4 \mathrm{~mm}(\mathrm{p}<0.05)$. Furthermore, the values for these parameters in the Nokoue Lake were higher than those obtained in the Ahémé Lake and in the coastal lagoon $(\mathrm{p}<0.05)($ Table-2).

Body weight and total length relationship in T. guineensis and in S. melanotheron

In T. guineensis, the values of growth rate ranged from 2.55 to 3.15 in Ahémé Lake, Nokoué Lake, the coastal lagoon, and the lagoon of Porto-Novo. In Ahémé Lake and coastal lagoon, the growth of T. guineensis was negative allometric $(\mathrm{b}<3)$ while in the lagoon of Porto-Novo, this species was positively allometric growth $(\mathrm{b}>3)$. By cons, $T$. guineensis of Nokoué Lake presented an isometric growth $(b=2.92)$ (Table-3). Regarding S. melanotheron, the values of growth coefficient in the Ahémé Lake, coastal lagoon, and Porto-Novo lagoon were, respectively, 2.07, 2.76, and 2.53. In these waterways, S. melanotheron presented a negative allometric growth. By cons, in Nokoue Lake the growth of these fish was isometric $(b=2.92)$ (Table-3). The body weight and total length relationship of $T$. guineensis and S. melanotheron were highly significant in Ahémé Lake, coastal lagoon, and lagoon of Porto-Novo $(\mathrm{p}<0.001)$.

Evaluation of the level of contamination by Salmonella and E. coli in T. guineensis and S. melanotheron taken from Lakes Ahémé, Nokoué; coastal lagoon, and the lagoon of Porto-Novo

The level of contamination of Salmonella and E. coli in T. guineensis and $S$. melanotheron taken from different waterways were presented in Table- 4 . In the coastal lagoon, $66.66 \%$ of the population of $S$. melanotheron were contaminated with $E$. coli against $59.52 \%$ of the population of T. guineensis $(\mathrm{p}<0.05)$. In Nokoué Lake, populations of T. guineensis were more contaminated with $60 \%$ against $20 \%$ in S. melanotheron. In the lagoon of Porto-Novo, we note the same registration with $30 \%$ in populations of $T$. guineensis and $10 \%$ in $S$. melanotheron ( $\mathrm{p}<0.001$ ). About the level of contamination of E. coli in T. guineensis and S. melanotheron in Ahémé Lake, no significant difference was observed. However, microbiological analyzes revealed no sample contamination by Salmonella sp.

\section{Discussion}

Morphometric parameters of T. guineensis and S. melanotheron

The results obtained in this study are in accordance with those obtained by Fousséni [9] in these same waterways in Southern Benin. In Nigeria, it reports that the morphometric parameters of S. melanotheron are higher than those of T. guineensis [10]. Other authors report that the quality and quantity of food, as well as environmental variables, affect fish growth [11]. This can explain the difference in morphometric parameters and body weight between $S$. melanotheron and T. guineensis. S. melanotheron is particularly suitable in estuaries and brackish water. It tolerates a very wide range of salinity and low dissolved oxygen levels. It is an omnivorous species whose food resources vary in accordance with the environment [12]. According to Halvorsen and Svenning [13], a temperature change causes a difference in growth. In the lagoon of Porto-Novo and Nokoué Lake, the temperature is lower than in the Lake Ahémé and coastal lagoon [9]. This also explains the low morphometric parameter of $T$. guineensis in these two rivers. The same authors relate that $T$. guineensis presents low morphometric parameters and a relatively low weight gain when the salinity and dissolved oxygen levels are high. In their natural environment, 
Table-2: Morphometric parameters of Sarotherodon melanotheron in different streams.

\begin{tabular}{lccccc}
\hline Parameters & $\begin{array}{c}\text { Aheme Lake } \\
(\mathbf{n = 4 1 )}\end{array}$ & $\begin{array}{c}\text { Nokoue Lake } \\
(\mathbf{n = 5 0 )}\end{array}$ & $\begin{array}{c}\text { coastal lagoon } \\
(\mathbf{n = 4 9 )}\end{array}$ & $\begin{array}{c}\text { Porto-Novo lagoon } \\
(\mathbf{n = 5 0 )}\end{array}$ & $\begin{array}{c}\text { Significance } \\
\text { Total length }(\mathrm{mm})\end{array}$ \\
$133.58 \pm 3.15^{\mathrm{c}}$ & $161.64 \pm 3.15^{\mathrm{b}}$ & $131.6 \pm 3.32^{\mathrm{c}}$ & $176.28 \pm 3.15^{\mathrm{a}}$ & $* * *$ \\
Standard length $(\mathrm{mm})$ & $102.56 \pm 2.4^{\mathrm{c}}$ & $123.16 \pm 2.4^{\mathrm{b}}$ & $98.87 \pm 2.53^{\mathrm{c}}$ & $135.54 \pm 2.4^{\mathrm{a}}$ & $* * *$ \\
Body weight $(\mathrm{g})$ & $48.1 \pm 4.65^{\mathrm{c}}$ & $86 \pm 4.65^{\mathrm{b}}$ & $52.44 \pm 4.90^{\mathrm{c}}$ & $113.00 \pm 4.65^{\mathrm{a}}$ & $* * *$ \\
\hline
\end{tabular}

Averages in the same row followed by different letters are significantly different at the $5 \% ; * * * p<0,001$

Table-3: Body weight and total length relationship in Tilapia guineensis and Sarotherodon melanotheron in streams in southern Benin.

\begin{tabular}{|c|c|c|c|c|c|c|c|c|}
\hline \multirow[t]{2}{*}{ Waterways } & \multirow{2}{*}{$\begin{array}{c}\text { Body weight } \\
\text { (g) }\end{array}$} & \multirow{2}{*}{$\begin{array}{l}\text { Total length } \\
\quad(\mathrm{cm})\end{array}$} & \multicolumn{3}{|c|}{ T. guineensis } & \multicolumn{3}{|c|}{ S. melanotheron } \\
\hline & & & $\mathbf{a}$ & b & $\mathbf{r}^{2}$ & $\mathbf{a}$ & b & $\mathbf{r}^{2}$ \\
\hline Aheme Lake & {$[15-75]$} & {$[8,6-15,8]$} & 0,06 & $2,55^{*}$ & 0,83 & 0,22 & $2,07 *$ & 0,78 \\
\hline Nokoue Lake & {$[20-170]$} & {$[11,2-20,5]$} & 0,02 & 2,92 & 0,8 & 0,02 & 2,92 & 0,82 \\
\hline coastal logon & {$[15-90]$} & {$[8,3-17,2]$} & 0,03 & $2,88^{*}$ & 0,83 & 0,04 & $2,76 *$ & 0,92 \\
\hline Lagon of Porto-Novo & {$[35-245]$} & {$[13,8-22,2]$} & 0,01 & $3,15^{*}$ & 0,95 & 0,08 & $2,53 *$ & 0,95 \\
\hline
\end{tabular}

The sign $\left(^{*}\right)$ indicates that the value is significantly different from 3 ; a is ordered to the origin of the regression line; $b$ or regression coefficient is the gradient of the regression line; $r^{2}$ is the coefficient of determination

Table-4: Contamination level of salmonella and E. coli in Tilapia guineensis and Sarotherodon melanotheron.

\begin{tabular}{|c|c|c|c|c|c|c|}
\hline \multirow[t]{2}{*}{ Waterways } & \multicolumn{2}{|c|}{ Escherichia coli (\%) } & \multirow[t]{2}{*}{ Significance } & \multicolumn{2}{|c|}{ Salmonella sp. (\%) } & \multirow[t]{2}{*}{ Significance } \\
\hline & $\begin{array}{l}\text { Sarotherodon } \\
\text { melanotheron }\end{array}$ & $\begin{array}{c}\text { Tilapia } \\
\text { guineensis }\end{array}$ & & $\begin{array}{l}\text { Sarotherodon } \\
\text { melanotheron }\end{array}$ & $\begin{array}{c}\text { Tilapia } \\
\text { guineensis }\end{array}$ & \\
\hline Aheme Lake & $30^{\mathrm{a}}$ & $26.83^{a}$ & NS & 0 & 0 & NS \\
\hline Nokoue Lake & $20^{\mathrm{a}}$ & $60^{\mathrm{b}}$ & $* * *$ & 0 & 0 & NS \\
\hline coastal logon & $66.66^{b}$ & $59.52^{\mathrm{a}}$ & $*$ & 0 & 0 & NS \\
\hline Lagon of Porto-Novo & $10^{\mathrm{b}}$ & $30^{\mathrm{a}}$ & $* * *$ & 0 & 0 & NS \\
\hline
\end{tabular}

Averages in the same row followed by different letters are significantly different at the $5 \%$; ***p $<0.001 ; * p<0.05$ and ${ }^{\mathrm{NS}} \mathrm{p}>0.05$

the average total weight obtained in $T$. guineensis $(64.11 \mathrm{~g})$ is higher than that obtained in fish breeding (44.34 g) by Toko-Imorou et al. [6]. In the same study, the population of $S$. melanotheron with highest morphometric parameters in the natural environment is found in Porto-Novo lagoon with an average weight of $113 \mathrm{~g}$ and a total length of $176.28 \mathrm{~mm}$. It showed that $S$. melanotheron is less efficient growth when it is bread in cages than when it is bread Acadja in lagoon environment [14]. Similarly, morphometric parameters, growth indicators, are influenced by the waterway effect in T. guineensis [15].

\section{Weight-length relationship}

In this study, the results obtained in T. guineensis in Ahémé Lake, coastal lagoon, and the lagoon of Porto-Novo are in accordance with those of Lalèyè et al. [16] at the Ahémé Lake. On the other hand, the research conducted by Fontaine et al. [15] in Ahémé Lake, the lagoon of Porto-Novo and Nokoué Lake from August to October 2013, reveal isometric growth in the first two waterways and allometric growth in the latter. These types of variations are also observed in Labeo barbus batesii during its growth [17]. These changes can be explained by the fact that the growth factor is related to biotic factors, abiotic and availability of food as well as to habitat type [18].

In this work, regarding S. melanotheron, allometric coefficients obtained, respectively, in the Ahémé
Lake, the coastal lagoon, and the lagoon of Porto-Novo are in accordance with those obtained by Fagnon [19] who reveals an allometric coefficient of 2.75 in the coastal lagoon and 2.73 in the lagoon of Porto-Novo.

\section{Bacteriological analyzes in $T$. guineensis and S. melanotheron}

The presence of E. coli in the intestine of T. guineensis and $S$. melanotheron is linked to unhealthy waterways [20]. The results obtained in this study are in accordance with those obtained by Sèdogbo [21] and Dègnon et al. [20] on shrimp in the Nokoué Lake and the Ahémé Lake. The poor quality of the captured fish species is due to the high level of bacterial contamination of streams [22,23]. Similarly, Dègnon et al. [24] reported high bacterial contamination of Trachurus trachurus by coliforms in Benin. The absence of Salmonella in samples analyzed may be explained by his absence in waterways or the influence of resistance of fish in relation to the bacteria. These results are consistent with those obtained by N'diaye [25] on fishery products in 1998 in Dakar.

\section{Conclusion}

This study allows understanding the morphometric parameters and weight of $S$. melanotheron and T. guineensis in some stream in Southern Benin. It appears that the morphometric parameters and weight of $T$. guineensis are lower than those of 
$S$. melanotheron. The evaluation of the microbiological quality revealed that $T$. guineensis is more contaminated with $E$. coli that $S$. melanotheron. Since these two species are very important in the commercial market, particular attention should be paid to different cooking techniques to prevent bacterial infections that can result from the consumption of these fish species. It would be also interesting to perform the analysis of bacterial contamination of edible parts of the studied fish since intestines are probably not consumed. In addition to state that there is a risk for the final consumer of those fish a quantification of the amount of the colony-forming unit of E. coli should be performed.

\section{Authors' Contributions}

The present study was a part of original research work by TJD. He conceptualized the aim of the study, designed, planned, and supervised the experiment. Collection of samples and execution of experimental study were done by him and AC. Analysis of data, interpretation of the results, and drafting of the manuscript were done by AC. TJD helped in the analysis, draft and revision of the manuscript. All authors read and approved the manuscript.

\section{Acknowledgments}

The fund for this research provide from the Department of Animals Health and Production. Polytechnic school of Abomey-Calavi/University of Abomey-Calavi, Benin.

The authors are thankful to Professor and Head, Department of Animals Health and Production, Polytechnic school of Abomey-Calavi/ University of Abomey-Calavi, Benin and Professor and Head, Laboratory of Hydrobiology and Aquaculture, Faculty of Agronomic Sciences, University of AbomeyCalavi,Benin for providing their infrastructure and scientific skills in carrying out the research work.

\section{Competing Interests} interests.

The authors declare that they have no competing

\section{References}

1. Fish direction (2013). Fish statistic, Benin.

2. Montchowui E, Chikou $A$, Kogbeto $M$, Lalèyè $P$. Biodiversity and structure of lac Hlan fish community in Benin. Int J Biol Chem Sci 2008;2:196-206.

3. Le Fur B, Wacogne D, Lorre S, Pilet M, Leroi F. Biopreservation applications via microbial cultures in the chain of seafood; 2012.

4. Olsen SJ, MacKinnon LC, Goulding JS, Bean NH, Slutsker L. Surveillance for foodborne-disease outbreaks - United States, 1993-1997. MMWR CDC Surveill Summ 2000;49:1-62.

5. Agonkpahoun E. Assessment of pollution of continental watersby toxic metals: Case of the Okpara River and Lake Nokoué in Benin. PhD memory Pharmacy, FSS /UAC; 2006. p. 87.

6. Toko-Imorou I, Attakpa YE, Elègbè H. Biological, zootechnic and nutritional performance of Tilapia guineensis in natural environments and breeding. Int J Biol Chem Sci 2010;4:1629-40.

7. Pilet C, Bourdon L, Toma B, Marchal N, Balbastre C. Medical and Veterinary Bacteriology, Bacterial Systematics. 2nd ed. 2nd print. Paris: Doin Editors; 1981. p. 431.

8. Statistical Analysis System. SAS/STAT User's Guide, Version 6. $4^{\text {th }}$ ed. Cary, NC, USA: SAS Institute; 2006.

9. Fousséni A. Ecology of Tilapia guineensis population Study in fresh waters in southern Benin. Master Thesis in Applied Hydrobiology. University of Abomey, Faculty of Science and Technology; 2013. p. 73.

10. Adéjonwo OA, Koladé OY, Ibrahim AO, Oramadiké CE, Ozor PA. Proximate and anatomical weight composition of wild brackish Tilapia guineensis and Tilapia melanotheron. Int J Food Saf 2010;12:100-3.

11. Boyd CE, Tucker CS. Pond Aquaculture Water Quality Management. Boston, Dordrecht, London: Kluwer Academic Publishers; 1998. p. 700.

12. Koné T, Teugels GG. Reproductive data of estuarine tilapia (Sarotherodon melanotheron) isolated in a dam lake of West African. Aquat Living Resour 1999;12:289-93.

13. Halvorsen H, Svenning MA. Growth of Atlantic Salmonparr in fluvial and lacustrine habitats. J Fish Biol 2000;57:145-60.

14. Legendre M. Aquaculture potential of cichlids (Sarotherodon melanotheron, Tilapia guineensis) and Clariidae (Heterobranchus longifilis) indigenous of Ivorian lagoons. PhD Thesis, University Montpellier II; 1991. p. 369.

15. Fontaine $\mathrm{P}$, Legendre $\mathrm{M}$, Vandeputte $\mathrm{M}$, Fostier A. Domestication of new species and sustainable development of fish farming. Cah Agric 2009;18:119-24.

16. Lalèyè $P$, Niyonkuru $C$, Moreau J, Teugels G. Spatial and seasonal distribution of the ichthyofauna of Nokoue Lake, Benin, West Africa. Afr J Aquat Sci 2003;28:151-61.

17. Coulibaly DN. Length-weight relationship in four fish species from the river Sourou in Burkina Faso. Int J Biol Chem Sci 2008;2:331-8.

18. Arslan M, Yidirim A, Bekta S. Length-weight relationships of brown trout, Salmo trutta L, inhabiting Kan Stream, Coruh Basin, North-Eastern Turkey. Turk J Fish Aquat Sci 2004;4:45-8.

19. Fagnon S. Morphological and ecological characterization of populations Sarotherodon melanotheron Rüppell, 1852 (Teleostei, Cichlidae) in fresh and brackish water in Benin. Master memory, EPAC /UAC; 2011. p. 71.

20. Dègnon R, Dahouenon-Ahoussi E, Adjou ES, Ayikpe O, Tossou S, Soumanou M, et al. Impact of Post-harvest treatments on the microbiological quality of the lake Ahémé shrimp in Benin for export. J Appl Biosci 2012;53:3749-59.

21. Sèdogbo YA. Impact of environmental pollution on the quality of the shrimp caught in Benin: South Fishery Nokoué Lake Case. Engineering Diploma Thesis, Polytechnic School of Abomey-Calavi, University of Abomey-Calavi; 2004. p. 106.

22. Badahoui A, Fiogbe E, Boko M. The causes of degradation of the lake Ahéméand it's oak. Int J Biol Chem Sci 2010;4:882-97.

23. Dovonou F, Aina M, Boukari M, Alassane A. Physicochemical and bacteriological pollution of an aquatic ecosystem and its ecotoxicological risk: Case of Nokoue lake in southern Benin. Int J Biol Chem Sci 2011;5:1590-602.

24. Dègnon RG, Agossou V, Adjou ES, Dahouénon-Ahoussi E, Soumanou MM, Sohounhloué CK. Evaluation of the microbiological quality of the mackerel (Trachurus trachurus) during the traditional smoking process. J Appl Biosci 2013;67:5210-8.

25. N'diaye A. Contribution to the study of the evolution of the bacteriological quality of fishery products for export in 1998 and 1997 Thesis Med Vet Dakar 1998;17:73. 